\title{
Republication: In That Case
}

\author{
Els Reijn • Marcel Verweij
}

Received: 30 January 2008 / Accepted: 30 January 2008 /Published online: 23 February 2008

(C) The Author(s) 2008

\section{Public Health Dilemmas Concerning a Two-year-old Hepatitis-B Carrier}

As a public health professional, you are notified that a 2-year-old boy in your town has been found to be a hepatitis B virus (HBV) carrier. The boy had been immunised (actively and passively) after birth because his mother was also a HBV-carrier. Such early immunisation prevents transmission from mother to child in most cases, but apparently this time it had not worked. Further investigation revealed that the child carried a specific genetic mutant of the virus (G145RHBV-mutant) which could explain why passive and active immunisation had failed. The boy has a high viral load. As a consequence, it is reasonable to recommend vaccination for all close contacts.

However, several questions arise. First, the child will probably go to a day nursery within a couple of months. Is that acceptable, given the risks of transmission (e.g. saliva on toys)? Should profession-

This article was originally published in Journal of Bioethical Inquiry 4(3): 245-246, http://dx.doi.org/10.1007/s11673-0079071-4. It is reprinted here for the sake of coherence.

Els Reijn is physician specialised in infectious diseases control. Marcel Verweij is bioethicist.

M. Verweij $(\bowtie)$

Ethics Institute, Utrecht University,

PO Box 80103, 3508 TC Utrecht, The Netherlands

e-mail: m.f.verweij@uu.nl

E. Reijn

Community Health Service Zaanstreek-Waterland,

Vurehout 2, 1507 EC Zaandam, The Netherlands als at the nursery be informed that the boy is a HBVcarrier? Should they take strict hygienic measures towards the boy? Should other parents be informed about the risk of infection? One option is to warn all parents that a child at the nursery is a carrier, and to offer them vaccination of their children. Such measures however may involve stigmatization of the boy.

Moreover, the fact that vaccination did not protect this child suggests that vaccination may be less effective in preventing infection with this specific HBV-mutant. Hence, does it make sense to offer vaccination to other children at the day nursery? In fact, there are reasons to think that normal vaccination does offer immunity to this mutant $[1,2]$, but not all experts agree with those reasons [3]. How should the (limited) evidence be weighed, and what are the implications for hygienic measures and information disclosure at the nursery?

Open Access This article is distributed under the terms of the Creative Commons Attribution Noncommercial License which permits any noncommercial use, distribution, and reproduction in any medium, provided the original author(s) and source are credited.

\section{References}

1. Boot, H. (2007). Hepatitis B-vaccinatie is óók effectief tegen de G145R-mutant. [Hepatitis B vaccination is also effective against G145R-mutant]. Infectieziektenbulletin, 18(6), 215-216.

2. Ogata, N., Cote, P. J., Zanetti, A. R., et al. (1999). Licensed recombinant hepatitis $\mathrm{B}$ vaccines protect chimpanzees against infection with the prototype surface gene mutant of hepatitis B virus. Hepatology, 30(3), 779-786.

3. Zuckerman, A. J. (2000). Effect of hepatitis B virus mutants on efficacy of vaccination. Lancet, 355, 1382-1384. 